九州大学学術情報リポジトリ

Kyushu University Institutional Repository

\title{
Changes in Mono-and Disaccharides Compositions of Guineagrass (Panicum maximum Jacq.) Si lage During Early Stages of Ensiling
}

Shao, Tao

Visiting Research Scientist from Lanzhou Institute of Animal Science and Veterinary Medicine of CAAS | Research Student, School of Agriculture, Kyushu University | Research Student, School of Agriculture, Kyushu University

Oba, Noriko

Research Student, School of Agriculture, Kyushu University

Shimojo, Masataka

Research Student, School of Agriculture, Kyushu University

Masuda, Yasuhisa

Research Student, School of Agriculture, Kyushu University

https://doi.org/10.5109/4503

出版情報: 九州大学大学院農学研究院紀要. 47 (2)，pp.333-339，2003-02-01. Faculty of Agriculture, Kyushu University

バージョン：

権利関係 : 


\title{
Changes in Mono-and Disaccharides Compositions of Guineagrass (Panicum maximum Jacq.) Silage During Early Stages of Ensiling
}

\author{
Tao SHAO ${ }^{1}$, Noriko OHBA ${ }^{2}$, Masataka SHIMOJO \\ and Yasuhisa MASUDA ${ }^{\dagger}$
}

\author{
Laboratory of Animal Feed Science, Division of Animal Science, Department of Animal \\ and Marine Bioresource Sciences, Faculty of Agriculture, \\ Kyushu University, Fukuoka 812-8581, Japan \\ (Received October 31, 2002 and accepted November 7, 2002)
}

\begin{abstract}
The dynamics of fermentation during the early stage of ensiling was studied with guineagrass (Panicum maximum Jacq.) ensiled in the laboratory silos of $100 \mathrm{ml}$ capacity. The silos were kept in the room set at $25^{\circ} \mathrm{C}$, and then were opened on $0.5,1,2,3,5$ and 7 days after ensiling, respectively. The samples were taken from three silos at each sampling time for chemical analyses. The results showed a slow decrease in $\mathrm{pH}$ and a slow increase in lactic acid content during the early stage of ensiling. The rate and extent of the full fermentation process was restricted, causing a high final $\mathrm{pH}$ value, low contents of lactic acid, acetic acid, total VFAs and total organic acids. No or only small amounts of butyric acid, valeric acid and propionic acid and low values of AN/TN at the end of ensiling implied that the silage was stable. However, there was an evidence that ethanol increased continuously as the major fermentation product and only detected level of residual mono-and disaccharides (fructose, glucose and sucrose) were found at the end of the experiment, indicating that alcoholic fermentation had taken place due to yeasts activity. The contents of mono-and disaccharides showed the largest decreases within the initial 0.5 day of ensiling, however, very low contents of fermentation products were detected, suggesting that the loss was caused mainly by plant respiration in this period. The rate of reduction in mono-and disaccharides compositions within initial 5 days of ensiling was ranked in the order of glucose $>$ fructose $>$ sucrose, suggesting that glucose and fructose might be more favorably utilized by microorganisms than sucrose.
\end{abstract}

\section{INTRODUCTION}

It is well known that air is still present in the silage during the early stage of ensiling and this enables plant respiration and aerobic microbial activity to take place, causing a loss of both fermentable substrates and nutritive materials. The rate and efficiency of acid production in the first stage of fermentation are important factors to both silage making and quality (Weinberg et al., 1988), therefore, the initial fermentation characteristics are critical to the success or failure of silage making.

Tropical grasses are generally low in water soluble carbohydrate (WSC) but high in polysaccharide contents (Smith, 1962) and have coarse, porosity and stemmy structures

\footnotetext{
1) Visiting Research Scientist from Lanzhou Institute of Animal Science and Veterinary Medicine of CAAS, Lanzhou Gansu Province of China

2) Research Student, School of Agriculture, Kyushu University

† Corresponding Author (E-mail: ymasuda@agr.kyushu-u.ac.jp)
} 
(Catchpoole and Henzell, 1971). Therefore, they are usually less dense and presumably more permeable, and relativity large quantities of air may be trapped in the forage mass than its temperate counterparts just after ensiling. These could cause a difference in the ensiling process and the silage quality between these species types (Kim and Uchida, 1990; Catchpoole and Henzell, 1971). According to McDonald et al. (1991), in temperate origin fructans are the most abundant WSC, however, grasses of tropical and subtropical originals accumulate starches instead of fructans. Yokota et al. (1991) and Miyagi et al. (1993) reported that a main preservative acid in napiergrass silage was lactic acid (LA). However, some researchers (Kim and Uchida, 1990; Catchpoole and Henzell, 1971) described that a main preservative acid in silages made from tropical grasses was acetic acid (AA). The WSC content is generally lower in tropical grasses than in temperate grasses, and how AA dominance proceeds during the fermentation of tropical grass silage is still not clear. Silages made from a number of tropical grasses have proved stable against anaerobic decomposition in the silo, as judged by low ratio of ammonia nitrogen to total nitrogen (AN/TN) and low butyric acid (BA) content, but their chemical composition does not conform to temperate standards for LA silage (Catchpoole and Henzell, 1971).

Guineagrass (Panicum maximum Jacq.) is one of the most important tropical forage crops. It is now widely distributed through tropical and subtropical regions of the world, and is often used as a silage making material. However, there is limited information regarding the changes in mono-and disaccharides and the production of organic acids during the early stage of ensiling. The purpose of the present work is to study the relation between the changes in mono-and disaccharides compositions and the fermentation quality in the early stages of guineagrass silage.

\section{MATERIALS AND METHODS}

\section{Silage making}

Guineagrass was cultivated in the experimental field of Kyushu University, Hakozaki, Fukuoka, Japan. The second growth of guineagrass was harvested at the milky ripe stage using a hand sickle on 18 October 1999. The harvested guineagrass was chopped into approximately $1 \mathrm{~cm}$ length with a forage cutter. The chopped grass was immediately collected and 85 grams were packed into a plastic laboratory silo ( $100 \mathrm{ml}$ capacity) in triplicates, followed by being sealed with a screw top and stored in the room kept at $25^{\circ} \mathrm{C}$. The silos were opened on $0.5,1,2,3,5$ and 7 days after ensiling.

\section{Chemical analyses}

The chopped grass was immediately collected for determining the contents of dry matter (DM), TN, crude protein (CP) and mono-and disaccharides compositions (fructose, glucose and sucrose). After the silos were opened and the contents were mixed thoroughly, 30 grams of the sample were taken from each silo. This was followed by adding 60 grams of distilled water and extracting at $4^{\circ} \mathrm{C}$ for 24 hours. Then, the extracts were filtered through two layers of cheesecloth and a filter paper (Toyo No. 5A) and the filtrates were stored at $-20^{\circ} \mathrm{C}$ prior to chemical analyses. The filtrates were used for determining $\mathrm{pH}, \mathrm{AN}, \mathrm{LA}$, ethanol, and volatile fatty acids (VFAs). The $\mathrm{pH}$ of silage was measured using a glass electrode $\mathrm{pH}$ meter (Horiba Co, Japan). TN was analyzed by the 
Kjeldahl method (AOAC, 1984) and AN with an ammonia electrode (Model IM-22P, Toa Electronics Ltd, Japan). CP was determined with 6.25 multiplied by TN. The LA content was determined using the method of Barker and Summerson (1941), and VFAs and ethanol with gas chromatography (Shimadzu GC-17A, Japan, with $12 \mathrm{~m}$ capillary column, condition: column temperature $100^{\circ} \mathrm{C}$, injection temperature $250^{\circ} \mathrm{C}$ ). The DM contents of the grass and silages were determined by drying in an oven at $65^{\circ} \mathrm{C}$ for at least 48 hours (AOAC, 1984), and DM of silage was recalculated with the contents of volatile compositions. Mono-and disaccharides compositions of the fresh guineagrass and silages were determined by high performance liquid chromatography (HPLC) as shown in our previous report (Shao et al., 2002).

\section{Statistical analyses}

All data were analyzed statistically by one-way analysis of variance with storage periods as a factor and statistical significance among storage periods for each item was determined by Fisher's least significant difference test; these were performed by ANOVA using the GLM procedure of the Statistical Analysis System (SAS, 1984).

\section{RESULTS}

The characteristics of guineagrass before ensiled were as follows; it contained intermediate contents of DM $(258.64 \mathrm{~g} / \mathrm{kg})$ and $\mathrm{CP}(79.35 \mathrm{~g} / \mathrm{kg})$, higher contents of fructose $(33.54 \mathrm{~g} / \mathrm{kg})$, glucose $(30.54 \mathrm{~g} / \mathrm{kg})$, sucrose $(80.27 \mathrm{~g} / \mathrm{kg})$ and total mono-and disaccharides $(144.34 \mathrm{~g} / \mathrm{kg})$.

The early fermentation characteristics of the guineagrass silage are presented in Table 1. The $\mathrm{pH}$ value decreased slowly from 5.68 to 5.35 , a slight but significant $(\mathrm{p}<$ 0.05 ) decrease from 2 days of ensiling. The LA content increased slowly from 1.53 to $6.15 \mathrm{~g} / \mathrm{kg}$, a small but significant $(\mathrm{p}<0.05)$ increase from 2 days of ensiling. The AA

Table 1. Changes in fermentation quality of guineagrass during the early stage of ensiling

\begin{tabular}{|c|c|c|c|c|c|c|}
\hline \multirow[b]{2}{*}{ Item } & \multicolumn{6}{|c|}{ Storage periods (days) } \\
\hline & 0.5 day & 1 day & 2 days & 3 days & 5 days & 7 days \\
\hline $\mathrm{pH}(\mathrm{SD})$ & $5.68(0.05) c^{1)}$ & $5.68(0.02) \mathrm{c}$ & $5.56(0.02) \mathrm{b}$ & $5.55(0.05) \mathrm{b}$ & $5.56(0.10) b$ & $5.35(0.10) a$ \\
\hline DM (SD) $\left(\mathrm{g} \mathrm{kg}^{-1}\right)$ & $256.10(0.74) \mathrm{a}$ & $254.50(4.22) \mathrm{a}$ & $253.89(1$ & $256.38(3.25) \mathrm{a}$ & $254.64(6.20) \mathrm{a}$ & 256.60 \\
\hline Ethanol (SD) ( $\left(\mathrm{kg}^{-1} \mathrm{DM}\right)$ & & $3.52(0.57) \mathrm{a}$ & .08) ab & $7.83(1.75) b$ & $15.30(4.84) \mathrm{C}$ & .88) d \\
\hline $\mathrm{LA}(\mathrm{SD})\left(\mathrm{g} \mathrm{kg}^{-1} \mathrm{DM}\right)$ & $1.53(0.21) \mathrm{a}$ & $2.23(0.68) a b$ & $3.85(0.20) b c$ & $5.48(0.82) \mathrm{cd}$ & $5.01(2.13) \mathrm{cd}$ & $6.15(0.69) \mathrm{d}$ \\
\hline $\mathrm{AA}(\mathrm{SD})\left(\mathrm{g} \mathrm{kg}^{-1} \mathrm{DM}\right)$ & $0.55(0.10) \mathrm{a}$ & $1.03(0.11) \mathrm{a}$ & $1.04(0.14) \mathrm{a}$ & $0.93(0.04) \mathrm{a}$ & $3.80(0.53) \mathrm{b}$ & $4.42(0.61) \mathrm{c}$ \\
\hline $\left.\mathrm{kg}^{-1} \mathrm{DM}\right)$ & 0.14( & $0.02(C$ & 0.00 & 0) a & 7) a & $30) \mathrm{b}$ \\
\hline $\mathrm{VA}$ (SD) $\left(\mathrm{g} \mathrm{kg}^{-1} \mathrm{DM}\right)$ & $b$ & $0.00(0.00) \mathrm{a}$ & 0.00( & $0.00(0.00) \mathrm{a}$ & 04) a & $04) \mathrm{a}$ \\
\hline & & & & & & \\
\hline VFAs (SD) $\left(\mathrm{g} \mathrm{kg}^{-1} \mathrm{DM}\right)$ & $1.14(0.55) \mathrm{a}$ & $1.13(0$ & $1.04(0.14) \mathrm{a}$ & $1.01(0.03) \mathrm{a}$ & $4.28(0.45) \mathrm{b}$ & $8.12(2.12) c$ \\
\hline Organic acids (SD) (g kg-1 DM) & $2.66(0.49) \mathrm{a}$ & $3.37(0.96) \mathrm{ab}$ & $4.89(0.20) b c$ & $6.48(0.83) \mathrm{c}$ & $9.29(1.72) \mathrm{d}$ & $14.22(1.82) \mathrm{e}$ \\
\hline LA/AA (SD) & $2.83(0.71) b c$ & $2.14(0.43) \mathrm{ab}$ & $3.76(0.56) \mathrm{c}$ & $5.86(0.93) \mathrm{d}$ & $1.39(0.79) \mathrm{a}$ & $1.42(0.33) \mathrm{a}$ \\
\hline $\mathrm{AN}(\mathrm{SD})\left(\mathrm{g} \mathrm{kg}^{-1} \mathrm{TN}\right)$ & $2.64(0.04) \mathrm{a}$ & $9.01(2.26) a b$ & $15.81(1.29) b c$ & $21.19(1.23) \mathrm{c}$ & $35.55(3.66) \mathrm{d}$ & $45.54(9.22) \mathrm{e}$ \\
\hline
\end{tabular}

1) Values followed by different letters in the same row show significant differences at $\mathrm{p}<0.05$. 
Table 2. Changes in contents of mono-and disaccharides of guineagrass during the early stage of ensiling ( $\left.\mathrm{g} \mathrm{kg}^{-1} \mathrm{DM}\right)$

\begin{tabular}{lrllllll}
\hline & \multicolumn{7}{c}{ Storage periods (days) } \\
\cline { 2 - 7 } \multicolumn{1}{c}{ Item } & 0 day & 0.5 day & 1 day & 2 days & 3 days & 5 days & 7 days \\
\hline Fructose (SD) & 33.54 & $21.39(3.77) \mathrm{cd}^{11}$ & $24.42(2.18) \mathrm{d}$ & $15.26(6.23) \mathrm{bc}$ & $9.63(3.81) \mathrm{b}$ & $1.62(1.57) \mathrm{a}$ & $0.87(0.75) \mathrm{a}$ \\
Glucose (SD) & 30.54 & $17.65(4.79) \mathrm{c}$ & $14.48(1.51) \mathrm{c}$ & $6.13(5.44) \mathrm{b}$ & $1.93(3.35) \mathrm{ab}$ & $0.00(0.00) \mathrm{a}$ & $0.00(0.00) \mathrm{a}$ \\
Sucrose (SD) & 80.27 & $34.22(8.90) \mathrm{c}$ & $34.32(7.34) \mathrm{c}$ & $16.48(5.01) \mathrm{b}$ & $6.08(2.15) \mathrm{ab}$ & $8.85(8.77) \mathrm{ab}$ & $0.00(0.00) \mathrm{a}$ \\
Mono-and disaccharides (SD) & 144.34 & $73.26(8.34) \mathrm{d}$ & $73.22(8.02) \mathrm{d}$ & $37.86(10.07) \mathrm{c}$ & $17.64(7.78) \mathrm{b}$ & $10.47(10.32) \mathrm{ab}$ & $0.87(0.75) \mathrm{a}$ \\
\hline
\end{tabular}

1) Values followed by different letters in the same row show significant differences at $p<0.05$.

content did not greatly change within initial 3 days of ensiling, and then increased significantly $(\mathrm{p}<0.05)$ to $4.42 \mathrm{~g} / \mathrm{kg}$. LA/AA gradually increased and reached the peak (5.86) on the day 3 of ensiling $(p<0.05)$, and then decreased significantly $(p<0.05)$ to 1.42. The total VFAs content showed a similar profile with AA, almost constant within the initial 3 days, and then increased significantly $(p<0.05)$ to $8.12 \mathrm{~g} / \mathrm{kg}$ at the end of the experiment. Total organic acids increased significantly $(\mathrm{p}<0.05)$ from 2 days of ensiling, and reached $14.22 \mathrm{~g} / \mathrm{kg}$ at the end of ensilage. The ethanol content gradually increased within initial 2 days of ensiling and then kept on increasing $(p<0.05)$ to $20.76 \mathrm{~g} / \mathrm{kg}$ on the 7 th day. The contents of BA, valeric acid (VA) and propionic acid (PA) were hardly detected during the initial 5 days of ensilage, however, there was a small but significant $(p<0.05)$ increase in BA and PA contents on the 7th day of ensiling. AN/TN significantly $(p<0.05)$ increased from 2 days of ensiling and reached $45.54 \mathrm{~g} / \mathrm{kg}$ at the end of ensiling. DM content did not change greatly up to 7 days of ensiling.

Changes in the contents of mono-and disaccharides during the ensiling are shown in Table 2. There were the largest decreases in mono-and disaccharides compositions (fructose, glucose and sucrose) within initial 0.5 day of ensiling from those of the original fresh guineagrass. Fructose tended to decrease $(p>0.05)$ between 0.5 and 2 days, and then decreased significantly $(\mathrm{p}<0.05)$ from 3 days to $0.87 \mathrm{~g} / \mathrm{kg}$ at the end of ensilage. Glucose decreased slowly between 0.5 day and 1 day of ensiling, and then decreased significantly $(p<0.05)$ to zero until 5 days of ensilage. Sucrose showed no changes between 0.5 day and 1 day of ensiling, and then decreased significantly $(p<0.05)$ to zero on the 7 th day of ensiling. The rate of disappearance in mono-and disaccharides compositions was ranked in the following order: glucose $>$ fructose $>$ sucrose within initial 5 days of ensiling.

\section{DISCUSSION}

Evidence has shown that the rate and extent of guineagrass silage fermentation was restricted throughout the ensiling period in this experiment. This was well indicated by a slow decrease in $\mathrm{pH}$ and a slow increase in LA content, resulting in high $\mathrm{pH}$ value, low contents of LA, AA, VFAs and total organic acids, and low AN/TN value at the end of ensiling. These results were different from our previous study (Shao et al., 2002), however, seem to be similar to the fermentation quality of wilted silages (McDonald et al., 1968; Anderson and Jackson, 1970; Marsh, 1979; Driehuis et al., 1997). We harvested guineagrass at the milky ripe stage with intermediate DM content $(258.64 \mathrm{~g} / \mathrm{kg})$ and high 
mono-and disaccharides content $(144.34 \mathrm{~g} / \mathrm{kg})$ but the material plant was very rigid. Nevertheless, the fermentation process was restricted. This could probably be attributed to the rigid physical properties of guineagrass at the milky ripe stage. It had a coarse, porosity and stemmy structures, and thus there might be a relatively larger quantity of air trapped in the forage mass just after ensiling, causing the delay in time for the air disappearance. These factors would make the cell breakdown and release of plant juice more difficult and slower, thereafter restricted the rate and extent of fermentation of guineagrass silage by epiphytic LAB. Greenhill (1964a, b, c) also reported that cell breakdown and release of intra-cellular plant juices are prerequisite for the initiation of LAB fermentation, and the complete exclusion of fresh air from the silage mass can usually be expected to result in cell breakdown and juice release.

The ethanol content continuously increased as a major fermentation product whereas mono-and disaccharides compositions (fructose, glucose and sucrose) continuously decreased throughout the fermentation process. There was a larger amount of ethanol compared to LA and AA, and it was likely that yeasts (aerobic bacteria) were responsible for the observed ethanol production (McDonald et al., 1991). The reasons for the predominance of ethanol rather than LA fermentation when the guineagrass high in fermentable sugers were ensiled in anaerobic conditions are not clear. McDonald et al. (1968) found more yeasts in silages of high DM content. In the present study it was probably due to the essentially different physical structure of guineagrass at the milky ripe stage as compared with temperate grasses, resulting in the slow release of juice and inhibition of the LA fermentation. The high $\mathrm{pH}$ value and low level production of LA and AA might stimulate yeast activity during ensiling (Alli et al., 1985; Driehuis et al., 1997). In addition there was a small but significant high BA and PA contents on the 7 th day of ensiling, which indicated some clostridial fermentation occurring. This was attributed to the high $\mathrm{pH}$ and some residual sucrose on the 5 th day of ensiling. Although there were a high $\mathrm{pH}$ value and low LA content at the end of ensiling, low AN/TN value $(45.54 \mathrm{~g} / \mathrm{kg}$ ) and no or only small amounts of BA, VA and PA detected during ensilage indicated a stable silage (Catchpoole and Henzell, 1971). Yokota et al. (1991) and Miyagi et al. (1993) reported that the ensiling nature of tropical species was LA fermentation, but others (Catchpoole and Henzell, 1971; Kim and Uchida, 1990) demonstrated that a main preservation in silages made from tropical grasses was AA. These were different from our present results, in which guineagrass had high mono-and disaccharides content but did not show LA or AA fermentation. The ethanol was a major fermentation product and almost all of mono-and disaccharides disappeared at the end of the experiment. This suggests that the physical structure of tropical grasses is also one of the important factors affecting the fermentation quality in the experiment. DM content did not change greatly up to 7 days of ensiling, which was due to the property of laboratory silo that was efficiently sealed and no seepage loss.

The contents of mono-and disaccharides compositions (fructose, glucose and sucrose) showed the largest decreases within initial 0.5 day of ensiling (Table 2), and very small amounts of fermentation products were detected (Table 1), suggesting that the loss was caused mainly by plant respiration in this period. This is similar to that found by other workers (Wylam, 1953; Carpintero et al., 1969; Seale, 1986). The rate of reduction in mono-and disaccharides compositions within initial 5 days of ensiling was ranked in the 
order of glucose $>$ fructose $>$ sucrose, suggesting that glucose and fructose might be more favorably utilized by microorganisms than sucrose. There were no initial rises in fructose and glucose content, which is different from previous studies on temperate grass silages (Masaki and Ohyama, 1979, Shao et al., 2002). This may be due to the absence of fructans in guineagrass, because tropical grasses accumulate starches instead of fructans.

\section{REFERENCES}

Alli, I., S. Pabari, R. Fairbairn and B. E. Baker 1985 The effects of sorbates on the ensilage of chopped whole-plant maize and lucerne. J. Sci. Food Agric., 36: 63-70

Anderson, B. K. and N. Jackson 1970 Conservation of wilted and unwilted grass ensiled in air-tight metal containers with and without the addition of molasses. J. Sci. Food Agric., 21: 235-241

AOAC, 1984. Official Methods of Analysis. Association of Official and Analytical Chemists 14 th ed. Arlington, Virginia, USA

Barker, S. B. and W. H. Summerson 1941 The colorimetric determination of lactic acid in biological material. J. Biol. Chem., 138: 535-554

Carpintero, M. C., A. J. Holding and P. McDonald 1969 Fermentation studies of lucerne. J. Sci. Food Agric., 29: 497-505

Catchpoole, V. R. and E. F. Henzell 1971 Silage and silage-making from tropical herbage species. Herb. Abstr., 41: 213-221

Driehuis, F., P. G. van Wikselaar, A. M. van Vuuren and S. F. Spoelstra 1997 Effect of a bacterial inoculant on rate of fermentation and chemical composition of high dry matter grass silage. J. Agric. Sci., 128: 323-329

Greenhill, W. L. 1964a Plant juices in relation to silage fermentation. I. The role of the juice. J. Br. Grassl. Soc., 19: 30-37

Greenhill, W. L. 1964b Plant juices in relation to silage fermentation. II. Factors affecting the release of juices. J. Br. Grassl. Soc., 19: 231-236

Greenhill, W. L. 1964c Plant juices in relation to silage fermentation. III. Effect of water activity of juice. J. Br. Grassl. Soc., 19: 336-339

Kim, K. H. and S. Uchida 1990 Comparative studies of ensiling characteristics between temperate and tropical species. 1. The effect of various ensiling conditions on the silage quality of Italian ryegrass (Lolium multiflorum Lam.) and Rhodegrass (Chloris gayana Kunth.). J. Japan. Grassl. Sci., 36: 292-299

Marsh, R. 1979 The effect of wilting on fermentation in the silo and the nutritive value of silage. Grass Forage Sci., 34: 1-10

Masaki, S. and Y. Ohyama 1979 Changes in sugars during ensilage-production of lactic acid and volatile fatty acids. Jap. J. Zootech. Sci., 50: 280-287 (In Japanese with English summary).

McDonald, P., A. R. Henderson and A. W. MacGregor 1968 Chemical changes and losses during the ensilage of wilted grass. J. Sci. Food Agric., 19: 125-132

McDonald, P., A. R. Henderson and S. J. E. Heron 1991 The Biochemistry of Silage (2 nd ed.) Cambrian Printers Ltd. Aberystwyth, pp. 184-223

Miyagi, E., Y. Kawamoto and Y. Masuda 1993 The effect of some pre-ensiling treatments on quality and palatability of napiergrass. J. Japan. Grassl. Sci., 39: 51-56 (In Japanese with English summary).

SAS Institute Inc. 1984 SAS/STAT User's Guide: Version 6. 4 th ed. SAS Institute Inc., Cary, North Carolina

Seale, D. R. 1986 Bacterial inoculants as silage additives. J. Appl. Bacteriol. Symp. Suppl., 9S-26S

Shao, T., N. Ohba, M. Shimojo and Y. Masuda 2002 Dynamics of early fermentation of Italian ryegrass (Lolium multiflorum Lam.) silage. Asian-Aust. J. Anim. Sci., 15: 1606-1610

Smith, L. H. 1962. Theoretical carbohydrate requirement for alfalfa silage production. Agron. J., 54: 291-293

Weinberg, Z. G., G. Ashbell and G. Azrieli 1988 The effect of applying lactic acid bacteria at ensilage on the chemical and microbiological composition of vetch, wheat and alfalfa silages. J. Appl. Bacteriol., 64: 1-7 
Wylam, C. 1953 Analytical studies on the carbohydrates of grasses and clovers. III. Carbohydrate breakdown during wilting and ensilage. J. Sci. Food Agric., 4: 527-531

Yokota, H., T. Okajima and M. Ohshima 1991 Effect of environmental temperature and addition of molasses on the quality of napier grass (Pennisetum purpureum Schum.) silage. Asian-Aust. J. Anim. Sci., 4: 377-382 